\title{
Performance e educação: [des]territorializações pedagógicas
}

\author{
João Batista Lima de Souza*
}

O termo performance tem significação múltipla e contextual. Múltipla porque gravita em seu entorno um variegado número de acepções e/ou aplicações; contextual porquanto seu caráter dinâmico dificultar, ou mesmo impossibilitar, delineamentos estanques. Averiguá-lo e discuti-lo, em vista disso, implica sopesar a existência de um leque de possibilidades para o seu emprego. No Brasil, emergem investigações acerca da performance, sobretudo na sua interface com os campos da educação, da filosofia, da antropologia, da sociologia e, especialmente, das artes. Assim, a instauração desse distinto campo de discussões abre um sem-número de caminhos a serem trilhados por interessados em verificar que a significação usualmente atribuída ao termo [desempenho de uma ação] é tão-somente um ponto situado neste horizonte pleno de questões a serem tomadas como objetos de estudo.

Em síntese, essa é a perspectiva articulada por Marcelo de Andrade Pereira (2013), em Performance e educação: [des]territorializações pedagógicas, que representa uma significativa, porque rica e vasta, tentativa de discutir o assunto em língua portuguesa. A obra apresenta quatorze textos, produtos do trabalho de investigação de diferentes autores ancorados em distintos temas filiados à temática. Precede os artigos uma sucinta apresentação que, já em seu primeiro parágrafo, pontua o fato de que, "no Brasil, os trabalhos nesta área são ainda incipientes" (PEREIRA, 2013, p. 7), o que autentica a obra na qual o leitor é conduzido por espaços lacunares, fronteiriços, intersticiais e flexíveis de onde é possível tecer saberes e experiências acerca da performance.

Da performance na educação: perspectivas para a pesquisa e a prática, de Gilberto Icle, serve ao propósito de apresentar um panorama sobre o termo performance, especialmente nas suas conexões com a educação. Contudo, retrocede para ir além: realiza uma retrospectiva com a intenção de descrever as mais diversas significações já formuladas, até hoje, para o termo. Já o organizador assina o segundo artigo, Performance docente: sentidos e implicações pedagógicas, realizando um contraponto à cultura do desempenho, que se percebe refletida na educação

Recebido: 19/06/2015 - Aprovado: 09/12/2015

http://dx.doi.org/10.5335/rep.v23i1.6367

Doutorando do Programa de Pós-Graduação em Educação da Universidade Federal de Santa Maria. Docente da rede municipal de ensino em Palmeira das Missões, RS. E-mail: jotabls@hotmail.com 
básica e no ensino superior, traduzindo uma "marca indiciária do redirecionamento e da ressignificação da formação no contexto de uma nova sociabilidade orientada pelo lucro e pela adaptação do indivíduo ao meio, ou seja, sob a égide do capital" (2013, p. 23).

Pedagogia crítico-performativa: encarnando a política da educação libertadora, de Elyse Lamm Pineau, tem por anelo propor, via performance, um modo de compreensão e de reconstrução das instituições escolares, "que disciplinam nossos corpos e mentes" (2013, p. 37). O escrito recomenda aos educadores críticos, mas também àqueles baseados na performance, alguns pressupostos que possibilitam suscitar novas questões de pesquisa e metodologias para o aperfeiçoamento do trabalho docente.

Bryan Keith Alexander, em Para analisar criticamente as interações pedagógicas como performance, propõe duas questões centrais: a) a noção de corpos políticos [professores e estudantes] ideologicamente inscritos e conflitantes em sala de aula; e b) a sala de aula, como local cultural, também se constitui em um espaço de negociação social. Em vista disso, o autor esclarece que "[...] essa confluência faz do ensino e da aprendizagem um ato social de negociação de modos de conhecer e agir" (2013, p. 60).

Ponderando que o ato de fala performativo é, também, um agir humano, "pois revela que, na fala autêntica, ao dizer algo realizamos efetivamente uma ação" (2013, p. 95), Pedagogia da performance: da arte da linguagem à linguagem da arte, de Elaine Conte, em coautoria com o organizador, trata de estabelecer paralelos que apontam para a performance docente, especialmente por intermédio da dimensão estético-expressiva, "capaz de produzir nos processos formativos um espaço de fluxo e de experimentação das coisas e do tempo, uma experiência que atualiza o mundo, estabelecendo uma relação pedagógica” (2013, p. 96).

O texto intitulado A memória dos objetos, de Naira Ciotti, pondera que "[...] o atual estado de arte indica uma virada epistemológica em direção à performance" (2013, p. 115), sendo esta uma nova oportunidade para a realização de produções artísticas dentro da escola.

Tatiana Mielczarski dos Santos assina Balé, performance e gênero, que estabelece como foco a ideia de que o balé implica uma performance artística que, justamente pelo seu gestual e indumentárias, se converte em uma performance de gênero, enaltecendo o feminino.

$\mathrm{Na}$ sequência, "A beleza poética das manifestações culturais que dependem de corpos em performance como matéria-prima de seu fazer" (2013, p. 147) surge como tônica no artigo Reflexões sobre os processos de produção do conhecimento performativo nas culturas populares, de Gisela Reis Biancalana. Situando a cultu- 
ra popular na contemporaneidade, a autora versa sobre os desdobramentos do conceito de cultura, enfatizando que as manifestações performativas populares estão assentadas no campo das atividades consideradas efêmeras, e que o corpo assume, assim, uma função expressiva.

Corpo: conceituações e exemplificações com Spinoza, de Paola Zordan, especifica que as performances são "atividades e práticas artísticas que procuram criar composições entre público e uma ação desenrolada no corpo do artista" (2013, p. 175). A autora classifica como performáticos não apenas todos os artistas, mas também professores e pessoas que, diante do encontro com o outro, potencializam essa relação e esse diálogo por intermédio de uma ética orientada pelos afetos alegres, encontros que, na prática, auxiliam os corpos na execução/realização de uma composição coletiva de um para com o outro.

Emergem das fronteiras entre Brasil, Argentina e Uruguai as problematizações propostas em Pequenos narradores e suas performances de fascínio e assombro, de Luciana Hartmann, que recorre a uma pesquisa tratando das performances dos contadores de causos e aduz aos estudos da performance na antropologia, alimentando sua argumentação a partir dos relatos de avós, tios e pais de estudantes que vivem nessas regiões acerca das narrativas de assombros, as quais foram recriadas em sala de aula.

Os nativos Assurini, do Xingú, compõem o background à frente do qual se inscreve o artigo de Regina Polo Müller, Performance e corpo e movimento no ritual indígena e nas artes cênicas: uma contribuição da antropologia, tratando da perspectiva da performance frente ao campo da etnologia indígena. A autora explicita que os corpos de bailarinos e atores contemporâneos, e também os corpos dos xamãs durante seus rituais, passaram a ser abordados "como elemento expressivo em linguagens artísticas e como discurso não verbal de sistemas de representações sensíveis" (2013, p. 219).

"Ressignificar a educação, via performance poético-existencial de seus atores e personagens, é reconhecer nesses atos seu alto valor estético enervado em condições tão inusitadas que se tornam inalcançáveis pelo vocabulário da razão" (2013, p. 249): eis aí um dos pontos-chave do artigo de Aldo Victorio Filho, A impossibilidade da educação versus sua íntima utopia: performance, estética e arte. $\mathrm{O}$ autor aborda $o$ ato performático e sua dimensão estética, em que "estranhamento, transtorno, imperícia, paixão e afetação regem a performance dos sujeitos encarnados que habitam a arena da aula" (2013, p. 235).

João Gabriel L. C. Teixeira assina A sociologia da dança: um experimento em samba de gafieira, oriundo da continuidade de um projeto experimental de pesquisa. Por intermédio desse projeto, e levando em consideração o fato de que "o 
corpo está na moda, e os estudos da performance tem oferecido e podem oferecer uma imensa variedade de formas e métodos para realizar essa descoberta" (2013, p. 259), o autor apresenta outra proposta para a perspectiva da performance, a de que a dança de gafieira pode fomentar o respeito ao corpo, em que se elucubra um universo simbólico.

E, por fim, o escrito de Inês Alcaraz Marocco, O sobrado: aproximações entre a performance e a pedagogia teatral, constitui-se em um relato problematizado [e autocrítico] da prática artística da autora, enfocando um espetáculo realizado durante $o$ ano de 2008, abordando a complexidade que circunda a criação artística e, sobretudo, a preparação do ator.

Extensa, variada, profunda, inovadora, instigante. Sobram adjetivos para qualificar a proposta do livro resenhado. Seu título já anuncia o objetivo de pensar as questões relativas às duas áreas mencionadas (performance e educação) no espaço nunca límpido, jamais envernizado, sempre nebuloso, eternamente efervescente de seus territórios. Todavia, o prefixo "des", entre colchetes no título, fornece uma importante pista ao leitor: reforça que a obra vai além de uma recolha de escritos sobre performance, propondo-se a refleti-la para além de uma função pedagógica ordinária.

Mais do que discutir as acepções para o termo performance, seus conceitos e suas possibilidades de aplicação no cenário educacional contemporâneo, Marcelo de Andrade Pereira apresenta ao público brasileiro os avanços nas teorizações do campo (ou anticampo) e da disciplina (ou antidisciplina), no intuito de jogar luz em algumas, somente algumas, das correlações, entrelaçamentos, agenciamentos e possibilidades de usos e abusos da performance, para problematizar uma educação e um mundo regidos sob a égide do fast, que aniquilam não só a experiência, mas automatizam corpos e sujeitos, e tolhem as significações das dimensões do agir humano.

\section{Referência}

PEREIRA, Marcelo de Andrade (Org.). Performance e educação: [des]territorializações pedagógicas. Santa Maria: Editora UFSM, 2013. 303 p. 